\title{
Predictors of cervical cancer screening among Kenyan women: results of a nested case-control study in a nationally representative survey
}

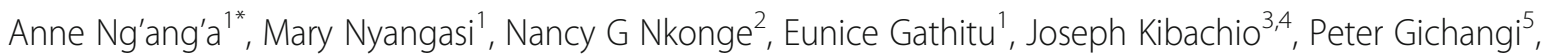
Richard G Wamai ${ }^{6}$ and Catherine Kyobutungi ${ }^{7}$

\begin{abstract}
Background: Cervical cancer is a major public health concern in Kenya. It is the leading cause of cancer morbidity and mortality among women. Although screening is an effective prevention method, uptake is low among eligible women. Little is known about predictors of cervical cancer screening uptake. This study explored relationship between uptake of cervical cancer screening, socio-demographic, behavioral and biological risk factors.

Methods: Nested case-control study within STEPS survey, a population-based cross-sectional household survey conducted between April and June 2015.Cases were women who had undergone cervical cancer screening and controls were unscreened women. Study participants were women eligible for cervical cancer screening (3049 years). Variables included socio-demographic; behavioral risk factors such as physical activity, tobacco and alcohol use diet and biological factors like diabetes and hypertension. Outcome of interest was cervical cancer screening. Data analysis was done using STATA version 14. Logistic regression model was used to assess relationship between cervical cancer screening and socio-demographic, behavioral and biological risk factors.

Results: Of 1180 women interviewed, 16.4\% $(n=194)$ had been screened for cervical cancer. Of unscreened women ( $n=986), 67.9 \%$ were aware of cervical cancer screening. Higher screening rates were observed in more educated women (25.2\%), highest income quintile (29.6\%) and living in urban areas (23\%) than in women with no formal education (3.2\%), poorest (3.6\%) and living in rural areas (13.8\%). Younger women (35-39) and those with low High-density lipoprotein (HDL) were less likely to be screened [OR $=0.56 ; 95 \% \mathrm{Cl}=(0.34,0.93) ; p$-value $=0.025]$ and $[O R=0.51 ; 95 \% \mathrm{Cl}=(0.29,0.91) ; \mathrm{p}=$ value 0.023$]$ respectively. Self-employed women, those in the fourth wealth quintile, binge drinkers, high sugar consumption and insufficient physical activity were more likely to be screened [OR $2.55(1.12,5.81) p$ value 0.026], [OR $3.56(1.37,9.28)$ p value 0.009], [OR $5.94(1.52,23.15) p$ value 0.010], [OR 2.99 $(1.51,5.89) p$ value 0.002$]$ and $[\mathrm{OR} 2.79(1.37,5.68) p$ value 0.005$]$ respectively.

Conclusion: Uptake of cervical cancer screening is low despite high awareness. Strategies to improve cervical cancer screening in Kenya should be implemented with messages targeting persons with both risky and non-risky lifestyles especially younger women with no formal education living in rural areas.
\end{abstract}

Keywords: Cervical cancer, Screening, Health behaviors, Kenya

\footnotetext{
* Correspondence: anniewambui@gmail.com

${ }^{1}$ NCD Division National Cancer Control Program, Ministry of Health, Nairobi,

Kenya

Full list of author information is available at the end of the article
}

(C) The Author(s). 2018 Open Access This article is distributed under the terms of the Creative Commons Attribution 4.0 International License (http://creativecommons.org/licenses/by/4.0/), which permits unrestricted use, distribution, and reproduction in any medium, provided you give appropriate credit to the original author(s) and the source, provide a link to the Creative Commons license, and indicate if changes were made. The Creative Commons Public Domain Dedication waiver (http://creativecommons.org/publicdomain/zero/1.0/) applies to the data made available in this article, unless otherwise stated. 


\section{Background}

Cancer is the second leading cause of death worldwide accounting for 8.7 million deaths globally in 2015 and 17.5 million new diagnoses with a $33 \%$ increase in cases between 2005 and 2015 [1]. Among this group of diseases, cervical cancer has in recent years been the leading cause of cancer deaths worldwide [2-4] with 239,000 deaths and 526,000 diagnoses in 2015 and most deaths being in sub-Saharan Africa (SSA) [1]. The global distribution and rising prevalence of cancer shows a worrisome 'cancer divide' where survival rates are low and outcomes poor among socioeconomically disadvantaged populations due to weak health systems, poor levels of education, and low awareness and screening coverages [5-10]. While cervical cancer is primarily caused by the sexually transmitted human papillomavirus (HPV) [11, 12], further variation is caused by differential prevalence levels of the infectious agent with SSA carrying the greater overall burden [13-16].

With close to 99,000 new cases and 57,400 deaths in 2012 alone [3], cervical cancer is emerging as a major public health problem in SSA $[17,18]$ where close to $90 \%$ of 443,000 projected annual global cervical cancer deaths by 2030 will occur [18]. This is due to population aging and growth, as well as increased prevalence of risk factors including those associated with social and economic transition [19-23]. Furthermore, as a sexually transmitted infection, behavioral factors are critical in the increased risk for HPV in high HIV prevalence setting in SSA where these infections are likely synergistic [24-29].

Although these are worrisome trends, it is noteworthy that attention to cervical cancer has been increasing in the past decade with major milestones and global commitments. These include: the development of three safe and effective HPV vaccines since 2006 [30-32], the 2009 World Health Organization's (WHO) position paper on HPV vaccines [33], 2011 Political Declaration on non-communicable diseases (NCDs) at the United Nations High-Level Meeting [34], the 2013 WHO Global action plan for the prevention and control of NCDs 2013-2020 [35], the Global Task Force on Expanded Access to Cancer Care and Control in Developing Countries [36], the commitment by GAVI Alliance in 2013 to support cervical cancer immunization at drastically reduced prices of $\$ 4.50$ per dose for Gardasil vaccine and $\$ 4.60$ per dose for Cevarix vaccine to qualifying countries [37], the 2014 WHO guidelines on cervical cancer screening [38] and in 2015 as reflected in the third Sustainable Development Goal (SDG) to reduce premature mortality due to NCDs by one-third by 2030 [39].

Despite these milestones and the high global burden of cervical cancer on SSA, screening and vaccine coverage remain overall very low [40-42] except for a few countries like Rwanda which reached 93\% of adolescent girls in grade six in 2011 [43]. Cervical cancer is preventable and curable in early stages through primary, secondary and tertiary interventions involving vaccination, early diagnosis and treatment [38]. In developed countries, screening and immunization has led to a marked reduction in incidence and mortality from cervical cancer [44, 45]. Drastically increasing screening availability will be a first crucial step to beginning to tackle cervical cancer in SSA. Although countries have started exploring strategies to address awareness, prevention, screening and immunization [41, 46-48] and research in these areas is increasing [49, $50]$, much remains to be done.

In Kenya, cervical cancer is the second most common cancer in women but the most common cause of cancer deaths [2, 51]. While accuracy of numbers are uncertain due to lack of a national cancer registry, of 2,354 women diagnosed in 2006 in the Nairobi Cancer Registry 65\% died [52]. The latest (2014) Kenya Demographic Health Survey (KDHS) shows a screening uptake of only $14 \%$ among women 30-49 years of age [53]. Although the Kenya government has developed a national cervical cancer prevention strategic plan [51] as well as conducted the vaccination pilot, rollout of the program has not yet commenced. Several studies on awareness and vaccine acceptability have been conducted in the country but only in some localized parts of the country such as Eldoret in the west [54-57], Nyanza [58, 59] and in Nairobi [60, 61]. A study from the Kitui pilot assessed primary school teachers' knowledge and acceptability of HPV vaccine [62]. These studies reveal high awareness and vaccine acceptability but also several factors contributing to the low screening uptake including lack of access to health facilities, cost, shortage of necessary supplies, inadequate and untrained staff, fear and perceived discomfort, long waiting time and lack of sufficient knowledge on the disease process. Many of these factors are also demonstrated in other low-and mid-income countries [10, 42, 63-66].

While some of the studies in Kenya assess behavioral risk factors and cervical cancer screening, it is not clear whether and which health behaviors can predict uptake of cervical cancer screening and no national-level data existed prior to the current study. The objective of this study was to determine the level of awareness of cervical cancer screening in women, examine the socio-demographic factors affecting cervical cancer screening, describe health behaviors in screened women and unscreened women and investigate whether biological risk factors predict uptake of cervical cancer screening using the first nationally representative survey on NCDs.

\section{Methods}

The nested unmatched case-control study design included all women between 30 and 49 years of age who had been recruited during the STEPS survey [67], a nationally representative survey conducted between May 
and June 2015. Written informed consent was sought from the selected individuals and confidentiality was maintained by all personal identifiers delinked by coding. The study protocol was approved by Kenya Medical Research Institute's Ethics Review Committee (SSC No. 2607).

Variables analyzed were behavioral risk factors as defined by the WHO STEPS instrument: current smoking habits, current alcohol consumption habits, diet and physical activity; socio-demographic factors such as age, residence, marital status, education level, wealth quintile and employment status and biological risk factors such as diabetes and, hypertension. The dependent variable was the screening status.

In the STEPS report, hypertension is defined by WHO as a systolic blood pressure $\geq 140 \mathrm{mmHg}$ and/or diastolic blood pressure $\geq 90 \mathrm{mmHg}$ and a fasting blood glucose of $>7 \mathrm{mmol} / \mathrm{l}$ is diagnostic of diabetes mellitus while a level of $6.1-7 \mathrm{mmol} / \mathrm{l}$ is known as impaired fasting glycaemia (pre-diabetic state); Descriptive analysis included frequencies and percentages of the sociodemographic variables. Prevalence of current smoking habits, current alcohol consumption habits, unhealthy diet and physical inactivity in the screened and unscreened women were also calculated.

We considered all the known cervical cancer risk factors in our data for analysis. Bivariate logistic regression models were run to assess the bivariate relationship between the different risk factors and the outcome of interest, cervical cancer screening. We then included all the risk factors of interest and those which had a $p$-value of less than 0.25 in the regression model. For the bivariate analyses comparing the study variables between screened and unscreened women, unpaired $\mathrm{t}$-test and Chi squared test were used for continuous variables and categorical variables, respectively. Odds ratio and its 95\% confidence interval were estimated and computed for each significant categorical factor using binary logistic regression. Conditional logistic regression analysis was performed to analyze the association between all categorical factors and screening status. All analyses were performed with STATA version 14 .

\section{Results}

\section{Sociodemographic characteristics, screening awareness} and behaviors

Descriptive data are presented in Table 1. More than half $(64.0 \%)$ of the women interviewed were between 30 and 39 years. Almost all (92.9\%) of them were either currently married or formerly married. Most (83.8\%) of them had received formal education in primary, secondary or tertiary levels of education. Homemakers and self-employed women constituted more than three quarters (79.6\%) of the participants. Participants were evenly distributed in the wealth quintile bands despite majority (71.6\%) of them living in the rural areas.
Half of the women (50.4\%) were aware of cervical cancer screening but only $16.4 \%$ had ever been screened. Of the unscreened women, $67.9 \%$ were aware of cervical cancer screening. Higher screening rates were observed in more educated women (25.2\%), women in the highest income quintile $(29.6 \%)$ and women living in urban areas $(23 \%)$ than in women with no formal education (3.2\%), women in the lowest income quintile $(3.6 \%)$ and in women living in rural areas (13.8\%).

Current tobacco users and alcohol drinkers were a small proportion of the women interviewed. A higher proportion $(84.2 \%)$ of participants consumed excess sugar compared to those who had inadequate fruit and vegetables intake (27.5\%), high salt intake (16.1\%) and insufficient physical activity. (6.4\%). Higher screening rates were found in tobacco non-users (16.7\%), binge drinkers (33.9\%), women with adequate fruits and vegetables intake (19.2\%), excess sugar intake (17.7\%), low salt intake (16.9\%) and insufficient physical activity (27.5\%) than in current tobacco users $(7.4 \%)$, alcohol non-drinkers (15.6\%), women with inadequate fruits and vegetables intake (9.1\%), less sugar intake (9.3\%), high salt intake (14.1\%) and sufficient physical activity (15.7\%).Higher screening rates were noticed in women with diabetes (24.7\%) and hypertension (17.2\%) than in women without diabetes $(16.3 \%)$ and without hypertension (13.7\%).

\section{Determinants of uptake of cervical cancer screening}

According to Table 2, younger women (35-39) and those with low HDL were less likely to be screened [OR 0.56 $(0.34,0.93) p$ value 0.025 ] and [OR $0.51(0.29,0.91) p$ value $0.023]$ respectively. Self-employed women, those in the fourth wealth quintile, binge drinkers, women with high sugar consumption and insufficient physical activity were more likely to be screened [OR $2.55(1.12,5.81) p$ value 0.026 ], [OR $3.56(1.37,9.28) p$ value 0.009 ], [OR 5.94 (1.52, 23.15) $p$ value 0.010 ], [OR $2.99(1.51,5.89) p$ value 0.002 ] and [OR $2.79(1.37,5.68) p$ value 0.005 ] respectively.

\section{Discussion}

This study results from the first nationally representative study of NCDs in Kenya. The study sought to assess the level of awareness of cervical cancer screening among women, describe health behaviors in screened women and unscreened women and determine predictors of cervical cancer screening. In 2015, 16.4\% of eligible Kenyan women had been screened for cervical cancer, a marginally higher figure than the 14\% shown in the 2014 KDHS [53]. Awareness of cervical cancer screening was high with $67.9 \%$ of unscreened women being aware, a lower level than in the KDHS where it was $76 \%$. The gap between awareness and uptake of cervical cancer screening is consistent with other studies. In a study done in Uganda, only $4.8 \%$ of women had undergone screening 
Table 1 Sociodemographic characteristics, screening awareness and behaviors by unscreened and screened

\begin{tabular}{|c|c|c|c|c|}
\hline \multirow[t]{2}{*}{ Characteristic } & \multicolumn{3}{|c|}{ Cervical Cancer Screened } & \multirow[b]{2}{*}{ Uncorrected Pearson Chi2 } \\
\hline & Unscreened (\%) & Screened (\%) & Total (\%) & \\
\hline \multicolumn{5}{|l|}{ Age groups } \\
\hline $30-34$ & $334(82.8)$ & $69(17.2)$ & $403(34.2)$ & \multirow{5}{*}{$\begin{array}{l}\operatorname{chi} 2(3)=15.26 \\
\text { p-value }=0.025\end{array}$} \\
\hline $35-39$ & $312(88.6)$ & $40(11.4)$ & $352(29.8)$ & \\
\hline $40-44$ & $195(76.9)$ & $59(23.1)$ & $253(21.4)$ & \\
\hline $45-49$ & $146(85.0)$ & $26(15.0)$ & $171(14.5)$ & \\
\hline Total & $986(83.6)$ & $194(16.4)$ & $1180(100)$ & \\
\hline \multicolumn{5}{|l|}{ Marital status } \\
\hline Not married & $68(82.1)$ & $15(17.9)$ & $83(7.0)$ & \multirow{4}{*}{$\begin{array}{l}\operatorname{chi} 2(2)=0.96 \\
p=0.753\end{array}$} \\
\hline Married & $761(84.2)$ & $143(15.8)$ & $903(76.5)$ & \\
\hline Formerly married & $157(81.5)$ & $36(18.5)$ & $193(16.4)$ & \\
\hline Total & $986(83.6)$ & $194(16.4)$ & $1180(100)$ & \\
\hline \multicolumn{5}{|l|}{ Education level } \\
\hline No formal education & $185(96.8)$ & $6(3.2)$ & $192(16.3)$ & \multirow{5}{*}{$\begin{array}{l}\operatorname{chi} 2(2)=44.11 \\
p<.000\end{array}$} \\
\hline Primary incomplete & $273(86.1)$ & $44(13.9)$ & $317(26.9)$ & \\
\hline Primary complete & $267(82.8)$ & $56(17.2)$ & $323(27.4)$ & \\
\hline Secondary and above & $261(74.8)$ & $88(25.2)$ & 349 (29.6) & \\
\hline Total & $986(83.6)$ & $194(16.4)$ & $1180(100)$ & \\
\hline \multicolumn{5}{|l|}{ Occupation } \\
\hline Unemployed & $76(87.4)$ & $11(12.6)$ & $87(7.4)$ & \multirow{7}{*}{$\begin{array}{l}\operatorname{chi} 2(5)=24.78 \\
p=0.006\end{array}$} \\
\hline Employed & $111(72.9)$ & $41(27.1)$ & $152(12.9)$ & \\
\hline Homemaker & $420(88.5)$ & $55(11.5)$ & $475(40.3)$ & \\
\hline Non-paid/volunteer & $1(100.0)$ & $0(0.0)$ & $1(0.1)$ & \\
\hline Self-employed & $378(81.4)$ & $86(18.6)$ & $464(39.3)$ & \\
\hline Student & $0(25.0)$ & $0(75.0)$ & $0(0.0)$ & \\
\hline Total & $986(83.6)$ & $194(16.4)$ & $1180(100)$ & \\
\hline \multicolumn{5}{|l|}{ Wealth band } \\
\hline Poorest & $257(96.4)$ & $9(3.6)$ & $266(22.5)$ & \multirow{6}{*}{$\begin{array}{l}\operatorname{chi} 2(4)=75.3041 \\
p<0.000\end{array}$} \\
\hline Second & $260(89)$ & $32(11)$ & $292(24.7)$ & \\
\hline Middle & $198(80.3)$ & $49(19.7)$ & $247(20.9)$ & \\
\hline Fourth & $137(74.7)$ & $46(25.4)$ & $183(15.5)$ & \\
\hline Richest & $135(70.4)$ & $57(29.6)$ & $192(16.3)$ & \\
\hline Total & $986(83.6)$ & $194(16.4)$ & $1180(100)$ & \\
\hline \multicolumn{5}{|l|}{ Residence } \\
\hline Rural & $729(86.2)$ & $117(13.8)$ & $845(71.6)$ & \multirow{3}{*}{$\begin{array}{l}\operatorname{chi} 2(1)=14.78 \\
p=0.006\end{array}$} \\
\hline Urban & $258(77.0)$ & $77(23.0)$ & $335(28.4)$ & \\
\hline Total & $986(83.6)$ & $194(16.4)$ & $1180(100)$ & \\
\hline \multicolumn{5}{|c|}{ Awareness of cervical cancer screening } \\
\hline No & $573(99.2)$ & $5(0.8)$ & $578(49.6)$ & \multirow{3}{*}{$\begin{array}{l}\operatorname{chi} 2(1)=206.71 \\
p<0.000\end{array}$} \\
\hline Yes & $399(67.9)$ & $189(32.1)$ & $588(50.4)$ & \\
\hline Total & $972(83.4)$ & $194(16.6)$ & $1166(100)$ & \\
\hline \multicolumn{5}{|l|}{ Current tobacco use } \\
\hline No & $948(83.3)$ & $190(16.7)$ & $1138(96.4)$ & \multirow{2}{*}{$\begin{array}{l}\operatorname{chi} 2(1)=2.60 \\
p=0.103\end{array}$} \\
\hline Yes & 39 (92.6) & $3(7.4)$ & $42(3.6)$ & \\
\hline
\end{tabular}


Table 1 Sociodemographic characteristics, screening awareness and behaviors by unscreened and screened (Continued)

\begin{tabular}{|c|c|c|c|c|}
\hline \multirow[t]{2}{*}{ Characteristic } & \multicolumn{3}{|c|}{ Cervical Cancer Screened } & \multirow[b]{2}{*}{ Uncorrected Pearson Chi2 } \\
\hline & Unscreened (\%) & Screened (\%) & Total (\%) & \\
\hline Total & $986(83.6)$ & $194(16.4)$ & $1180(100)$ & \\
\hline \multicolumn{5}{|l|}{ Episodic alcohol drinking } \\
\hline No alcohol & $952(84.4)$ & $176(15.6)$ & $1128(95.8)$ & \multirow{4}{*}{$\begin{array}{l}\operatorname{chi} 2(2)=12.16 \\
p=0.134\end{array}$} \\
\hline Binge drinking & $18(66.1)$ & $9(33.9)$ & $28(2.4)$ & \\
\hline Non-heavy drinking & $16(66.0)$ & $8(34.0)$ & $24(2)$ & \\
\hline Total & $984(83.6)$ & $194(16.4)$ & $1178(100)$ & \\
\hline \multicolumn{5}{|c|}{ Inadequate fruits and vegetables } \\
\hline No & $691(80.8)$ & $164(19.2)$ & $855(72.5)$ & \multirow{3}{*}{$\begin{array}{l}\operatorname{chi} 2(1)=17.28 \\
p=0.001\end{array}$} \\
\hline Yes & $296(90.9)$ & $30(9.1)$ & $325(27.5)$ & \\
\hline Total & $986(83.6)$ & $194(16.4)$ & $1180(100)$ & \\
\hline \multicolumn{5}{|l|}{ Excess sugar } \\
\hline No & $168(90.7)$ & $17(9.3)$ & $186(15.8)$ & \multirow{3}{*}{$\begin{array}{l}\operatorname{chi} 2(1)=8.10 \\
p=0.024\end{array}$} \\
\hline Yes & $818(82.3)$ & $176(17.7)$ & $994(84.2)$ & \\
\hline Total & $986(83.6)$ & $194(16.4)$ & $1180(100)$ & \\
\hline \multicolumn{5}{|l|}{ Actual intake of salt } \\
\hline Low salt ( 7 and below & $823(83.2)$ & $167(16.9)$ & $990(83.9)$ & \multirow{3}{*}{$\begin{array}{l}\operatorname{chi} 2(1)=0.08 \\
p=0.840\end{array}$} \\
\hline High (above 7) & $163(85.9)$ & $27(14.1)$ & $190(16.1)$ & \\
\hline Total & 986 (83.6) & $194(16.4)$ & $1180(100)$ & \\
\hline \multicolumn{5}{|l|}{ Physical activity } \\
\hline Sufficient & $932(84.4)$ & $173(15.7)$ & 1105 (93.6) & \multirow{3}{*}{$\begin{array}{l}\operatorname{chi} 2(1)=7.15 \\
p=0.020\end{array}$} \\
\hline Insufficient & $55(72.6)$ & $21(27.5)$ & $75(6.4)$ & \\
\hline Total & 986 (83.6) & $194(16.4)$ & $1180(100)$ & \\
\hline \multicolumn{5}{|l|}{ Diabetic } \\
\hline No & $900(83.7)$ & $175(16.3)$ & 1075 (97.1) & \multirow{3}{*}{$\begin{array}{l}\operatorname{chi} 2(1)=1.60 \\
p=0.332\end{array}$} \\
\hline Yes & $24(75.3)$ & $8(24.7)$ & $32(2.9)$ & \\
\hline Total & $924(83.5)$ & $183(16.5)$ & $1107(100)$ & \\
\hline \multicolumn{5}{|l|}{ Hypertensive } \\
\hline No & $296(86.3)$ & $47(13.7)$ & $342(29.4)$ & \multirow{3}{*}{$\begin{array}{l}\operatorname{chi} 2(1)=2.24 \\
p=0.233\end{array}$} \\
\hline Yes & $680(82.8)$ & 141 (17.2) & $822(70.6)$ & \\
\hline Total & 976 (83.8) & 188 (16.2) & $1164(100)$ & \\
\hline
\end{tabular}

for cervical cancer despite high levels of knowledge about cervical cancer and its risk factors [68].

Higher screening rates were seen in older, more educated, richer women and those living in urban areas. This is similar to a study done in Tanzania [69]. Older women are more likely to have interacted with the health system longer and therefore more likely to have undergone cervical cancer screening. A study in France found high screening rates among younger women aged 25-35 year [70]. The explanation for this was the screening services provided during antenatal visits. This calls for integration of cervical cancer services within the Kenya health system to avoid missed opportunities. While this is noted in various national health documents notably the National Cervical Cancer Prevention Program [52], the current practice shows a lack of cervical cancer services across the public health system [53]. Access to health services in rural areas has been cited as a barrier in other African setting [69] and could explain the higher screening rates among urban women. Even though cervical cancer screening is free in the public health sector in Kenya, additional costs such as transport may explain low screening rates among the women in lower wealth quintiles. Programs to increase cervical cancer screening should factor in hidden costs such as transport or lost earnings as women seek screening services especially in asymptomatic phase. 
Table 2 Determinants of uptake of cervical cancer screening

\begin{tabular}{|c|c|c|c|c|}
\hline \multirow[t]{2}{*}{ Cancer screen } & \multicolumn{2}{|l|}{ Crude Odds Ratio } & \multicolumn{2}{|l|}{ Adjusted Odds Ratio } \\
\hline & OR $(95 \% \mathrm{Cl})$ & $p$-value & OR $(95 \% \mathrm{Cl})$ & p-value \\
\hline \multicolumn{5}{|l|}{ Age group } \\
\hline $30-34$ & 1.00 & & 1.00 & \\
\hline $35-39$ & $0.62(0.41,0.94)$ & 0.024 & $0.54(0.32,0.90)$ & 0.018 \\
\hline $40-44$ & $1.45(0.98,2.14)$ & 0.063 & $1.50(0.90,2.52)$ & 0.121 \\
\hline $45-49$ & $0.85(0.52,1.39)$ & 0.517 & $1.00(0.53,1.88)$ & 0.988 \\
\hline \multicolumn{5}{|l|}{ Marital status } \\
\hline Not married & 1.00 & & & \\
\hline Married & $0.86(0.48,1.55)$ & 0.618 & $1.48(0.73,3.02)$ & 0.275 \\
\hline Formerly married & $1.04(0.53,2.02)$ & 0.912 & $1.58(0.70,3.59)$ & 0.270 \\
\hline \multicolumn{5}{|l|}{ Education level } \\
\hline No formal education & 1.00 & & 1.00 & \\
\hline Primary incomplete & $4.80(2.03,11.34)$ & 0.000 & $0.83(0.28,2.53)$ & 0.749 \\
\hline Primary complete & $6.21(2.65,14.51)$ & 0.000 & $0.63(0.20,1.99)$ & 0.426 \\
\hline Secondary and above & $10.03(4.35,23.12)$ & 0.000 & $0.76(0.24,2.46)$ & 0.653 \\
\hline \multicolumn{5}{|l|}{ Occupation } \\
\hline Unemployed & 1.00 & & 1.00 & \\
\hline Employed & $2.59(1.25,5.36)$ & 0.010 & $1.76(0.69,4.52)$ & 0.236 \\
\hline Homemaker & $0.91(0.45,1.81)$ & 0.783 & $2.24(0.99,5.10)$ & 0.054 \\
\hline Non-paid/volunteer & 1 (empty) & & 1 (empty) & \\
\hline Self-employed & $1.59(0.81,3.12)$ & 0.180 & $2.55(1.12,5.81)$ & 0.026 \\
\hline Student & $20.92(0.02,22921.15)$ & 0.395 & $545.08(0.34,873199.6)$ & 0.094 \\
\hline \multicolumn{5}{|l|}{ Wealth band } \\
\hline Poorest & 1.00 & & 1.00 & \\
\hline Second & $3.35(1.59,7.04)$ & 0.001 & $1.48(0.59,3.74)$ & 0.403 \\
\hline Middle & $6.63(3.23,13.62)$ & 0.000 & $2.26(0.92,5.59)$ & 0.076 \\
\hline Fourth & $9.18(4.43,19.02)$ & 0.000 & $3.12(1.19,8.21)$ & 0.021 \\
\hline Richest & $11.39(5.55,23.36)$ & 0.000 & $2.19(0.76,6.31)$ & 0.148 \\
\hline \multicolumn{5}{|l|}{ Residence } \\
\hline Rural & 1.00 & & 1.00 & \\
\hline Urban & $1.87(1.35,2.57)$ & 0.000 & $0.82(0.51,1.33)$ & 0.421 \\
\hline \multicolumn{5}{|l|}{ Heard of cervical cancer } \\
\hline No & 1.00 & & 1.00 & \\
\hline Yes & $59.47(23.29,151.87)$ & 0.000 & $66.75(23.77,187.43)$ & 0.000 \\
\hline \multicolumn{5}{|l|}{ Tobacco use } \\
\hline No & 1.00 & & 1.00 & \\
\hline Yes & $0.40(0.12,1.27)$ & 0.119 & $0.71(0.12,4.42)$ & 0.717 \\
\hline \multicolumn{5}{|l|}{ Alcohol consumption } \\
\hline No alcohol & 1.00 & & 1.00 & \\
\hline Binge drinking & $2.78(1.25,6.19)$ & 0.012 & $5.94(1.52,23.15)$ & 0.010 \\
\hline Non-heavy drinking & $2.78(1.18,6.60)$ & 0.020 & $3.78(0.96,14.84)$ & 0.057 \\
\hline \multicolumn{5}{|c|}{ Inadequate fruits and vegetables } \\
\hline No & 1.00 & & 1.00 & \\
\hline Yes & $0.42(0.28,0.64)$ & 0.000 & $0.79(0.46,1.37)$ & 0.404 \\
\hline
\end{tabular}


Table 2 Determinants of uptake of cervical cancer screening (Continued)

\begin{tabular}{|c|c|c|c|c|}
\hline \multirow[t]{2}{*}{ Cancer screen } & \multicolumn{2}{|l|}{ Crude Odds Ratio } & \multicolumn{2}{|c|}{ Adjusted Odds Ratio } \\
\hline & OR $(95 \% \mathrm{Cl})$ & $p$-value & OR $(95 \% \mathrm{Cl})$ & $\mathrm{p}$-value \\
\hline \multicolumn{5}{|l|}{ Excess sugar } \\
\hline No & 1.00 & & 1.00 & \\
\hline Yes & $2.10(1.25,3.54)$ & 0.005 & $3.17(1.61,6.21)$ & 0.001 \\
\hline \multicolumn{5}{|l|}{ Salt intake } \\
\hline Low & 1.00 & & 1.00 & \\
\hline High (above 7) & $0.81(0.52,1.26)$ & 0.344 & $1.17(0.65,2.12)$ & 0.601 \\
\hline \multicolumn{5}{|l|}{ Physical activity } \\
\hline Sufficient & 1.00 & & 1.00 & \\
\hline Insufficient & $2.04(1.20,3.47)$ & 0.009 & $2.76(1.34,5.67)$ & 0.006 \\
\hline \multicolumn{5}{|l|}{ Diabetes } \\
\hline No & 1.00 & & 1.00 & \\
\hline Yes & $1.68(0.74,3.81)$ & 0.211 & $1.37(0.46,4.13)$ & 0.574 \\
\hline \multicolumn{5}{|l|}{ Hypertension } \\
\hline No & 1.00 & & 1.00 & \\
\hline Yes & $1.31(0.92,1.88)$ & 0.135 & $0.99(0.64,1.55)$ & 0.974 \\
\hline \multicolumn{5}{|l|}{$\mathrm{HDL}$} \\
\hline Normal & 1.00 & & 1.00 & \\
\hline Low & $0.67(0.41,1.09)$ & 0.104 & $0.50(0.28,0.88)$ & 0.016 \\
\hline
\end{tabular}

Our study had interesting findings regarding health behaviors. There were higher rates of screening among tobacco non-users, those with adequate fruit and vegetable intake and low salt intake. We also found high rates of screening among binge drinkers, those with excess sugar intake and those with insufficient physical activity. These results are consistent with another study [70] that showed that screening uptake is not predictable based on health behaviors. This suggests that primary prevention programs should target all populations including those with healthy lifestyles and not just those with risky lifestyles.

Our paper also looked at screening uptake among women with diabetes and hypertension. Women with diabetes and hypertension had higher screening rates than those without. These findings are in contrast to existing literature except for hypertension. A study in the US showed that women with hypertension had increased odds of screening for breast cancer than non-hypertensives but no difference for cervical cancer screening [71]. The explanation for higher screening rate in the Kenyan women could be due to frequent contact with health care though other literature suggests quality of chronic disease care explains uptake of cancer screening and not necessarily frequent visits to health facilities [72].

This study had limitations. The uptake of cervical cancer screening was based on self-reports, with possible social desirability bias or recall bias. There was no data collected on frequency of screening, method used or where the screening was conducted. We are therefore not able to examine the most frequently used method or venue of screening. We cannot explore if the cervical cancer screening introduced in public health facilities is functional or not. Further studies are required to determine where women receive their cervical cancer screening and methods used for screening to better address the barriers to access or uptake of cervical cancer screening.

\section{Conclusion}

In conclusion, the study showed that among women aged 30-49 years, in terms of socio-demographic characteristics, those that were most likely to be screened were those in the age group 40-44 years, formerly married, the more educated women, and self-employed, richest women and living in urban areas.

For the behavioral risk factors, higher screening rates were found in tobacco non-users, alcohol binge drinkers, women with adequate fruits and vegetables intake, excess sugar intake, low salt intake and insufficient physical activity.

For biological risk factors, higher screening rates were observed in diabetics, hypertensives and in women with normal HDL.

As Kenya prepares to roll out the national HPV vaccination program in 2019, there is need to increase public awareness on the need for cervical cancer screening and develop strategies on the same to ensure increased 
screening uptake, early detection and better treatment outcomes. Advocacy initiatives should focus on younger women aged 35-39 years, and persons with risky as well as non-risky lifestyles.

\section{Abbreviations}

HDL: High density lipoprotein; HPV: Human Papilloma virus; LDL: Low density lipoprotein; MOH: Ministry of health; NCD: Non-communicable diseases

\section{Acknowledgements}

CORE funding for the main survey was provided by World Bank, WHO, AstraZeneca and $\mathrm{MOH} / \mathrm{CDC}$. We are also grateful to the data collection and analysis team led by the Ministry of Health, WHO and Kenya National Bureau of statistics, Kenya Medical Research Institute (KEMRI) and African Institute for Health and Development (AIHD). We would also like to thank the study participants for their time and IDRC for providing the time to write the article.

\section{Funding}

Publication of this supplement has been funded by International

Development Research Centre (IDRC) grant number 107209-001, through the African Population and Health Research Center (APHRC).

\section{Availability of data and materials}

Study materials and de-identified data are available by contacting Gladwell Gathecha at NCD unit Ministry of Health. gladwellgathecha@gmail.com.

\section{About this supplement}

This article has been published as part of BMC Public Health Volume 18 Supplement 3, 2018: Special issue from national survey on NCD risk factors in Kenya. The full contents of the supplement are available online at https:// bmcpublichealth.biomedcentral.com/articles/supplements/volume-18supplement-3.

\section{Authors' contributions}

AN coordinated the study. AN, MN, NG, EG conducted the literature review and analysis and wrote the first draft manuscript. JK, PG, CK, RGW reviewed the draft manuscript, provided critical comments. AN, MN NG finalized the manuscript. All authors have read and approved the final manuscript.

\section{Ethics approval and consent to participate}

The ethics committee at Kenya Medical Research Institute approved this study (SSC No. 2607).

\section{Consent for publication}

Not applicable.

\section{Competing interests}

The authors declare that they have no competing interests.

\section{Publisher's Note}

Springer Nature remains neutral with regard to jurisdictional claims in published maps and institutional affiliations.

\section{Author details \\ ${ }^{1}$ NCD Division National Cancer Control Program, Ministry of Health, Nairobi, Kenya. ${ }^{2}$ Division of Pharmacy, Kenyatta National Hospital, Nairobi, Kenya. ${ }^{3}$ Division of Non Communicable Diseases, Ministry of Health, Nairobi, Kenya. ${ }^{4}$ The Institute of Global Health, Faculty of Medicine, University of Geneva (UNIGE), Geneva, Switzerland. ${ }^{5}$ Department of Human Anatomy, University of Nairobi, Nairobi, Kenya. ${ }^{6}$ Department of Cultures, Societies and Global Studies, North Eastern University, Massachusetts, USA. ${ }^{7}$ African Population and Health Research Centre, Nairobi, Kenya.}

\section{Published: 7 November 2018}

\section{References}

1. Global Burden of Disease Cancer Collaboration C, Fitzmaurice C, Allen C, Barber RM, Barregard L, Bhutta ZA, et al. Global, Regional, and National Cancer Incidence, Mortality, Years of Life Lost, Years Lived With Disability, and Disability-Adjusted Life-years for 32 Cancer Groups, 1990 to 2015: A
Systematic Analysis for the Global Burden of Disease Study. JAMA Oncol. 2017;3(4):524-48 [cited 2017 Nov 5]; Available from: http://www.ncbi.nlm. nih.gov/pubmed/27918777.

2. Ferlay J, Shin H-R, Bray F, Forman D, Mathers C, Parkin DM. Estimates of worldwide burden of cancer in 2008: GLOBOCAN 2008. Int J Cancer. 2010 127(12):2893-917 [cited 2017 Nov 5]; Available from: http://www.ncbi.nlm. nih.gov/pubmed/21351269

3. Ferlay J, Soerjomataram I, Dikshit R, Eser S, Mathers C, Rebelo M, et al. Cancer incidence and mortality worldwide: Sources, methods and major patterns in GLOBOCAN 2012. Int J Cancer. 2015;136(5):E359-86 [cited 2017 Nov 5] Available from: http://www.ncbi.nlm.nih.gov/pubmed/25220842.

4. Torre LA, Bray F, Siegel RL, Ferlay J, Lortet-Tieulent J, Jemal A. Global cancer statistics, 2012. CA Cancer J Clin. 2015;65(2):87-108 [cited 2017 Nov 5]; Available from: http://www.ncbi.nlm.nih.gov/pubmed/25651787.

5. Coleman MP, Quaresma M, Berrino F, Lutz J-M, De Angelis R, Capocaccia R, et al. Cancer survival in five continents: a worldwide population-based study (CONCORD). Lancet Oncol. 2008;9(8):730-56 [cited 2017 Nov 5]; Available from: http://www.ncbi.nlm.nih.gov/pubmed/18639491.

6. Stringhini S, Berkman L, Dugravot A, Ferrie JE, Marmot M, Kivimaki M, et al. Socioeconomic status, structural and functional measures of social support, and mortality: The British Whitehall II Cohort Study, 1985-2009. Am J Epidemiol. 2012;175(12):1275-83 [cited 2017 Nov 5]; Available from: http:// www.ncbi.nlm.nih.gov/pubmed/22534202

7. Stringhini S, Sabia S, Shipley M, Brunner E, Nabi H, Kivimaki M, et al. Association of socioeconomic position with health behaviors and mortality. JAMA. 2010;303(12):1159-66 [cited 2017 Nov 5]; Available from: http://www. ncbi.nlm.nih.gov/pubmed/20332401.

8. Coleman MP. Cancer survival: global surveillance will stimulate health policy and improve equity. Lancet. 2014;383(9916):564-73 [cited 2017 Nov 5]; Available from: http://www.ncbi.nlm.nih.gov/pubmed/24351320.

9. Denny L, Quinn M, Sankaranarayanan R. Screening for cervical cancer in developing countries. Vaccine. 2006;24(Suppl 3):S3/71-7 [cited 2017 Nov 5]; Available from: http://www.ncbi.nlm.nih.gov/pubmed/16950020.

10. Randall TC, Ghebre R. Challenges in Prevention and Care Delivery for Women with Cervical Cancer in Sub-Saharan Africa. Front Oncol. 2016;6:160 [cited 2017 Nov 5]; Available from: http://www.ncbi.nlm.nih.gov/pubmed/27446806.

11. Muñoz N, Bosch FX, de Sanjosé S, Herrero R, Castellsagué X, Shah KV, et al. Epidemiologic Classification of Human Papillomavirus Types Associated with Cervical Cancer. N Engl J Med. 2003;348(6):518-27 [cited 2017 Nov 5]; Available from: http://www.ncbi.n/m.nih.gov/pubmed/12571259.

12. Burd EM. Human papillomavirus and cervical cancer. Clin Microbiol Rev. 2003;16(1):1-17 [cited 2017 Nov 5]; Available from: http://www.ncbi.nlm.nih. gov/pubmed/12525422.

13. Clifford G, Gallus S, Herrero R, Muñoz N, Snijders P, Vaccarella S, et al. Worldwide distribution of human papillomavirus types in cytologically normal women in the International Agency for Research on Cancer HPV prevalence surveys: a pooled analysis. Lancet. 2005;366(9490):991-8 [cited 2017 Nov 5]; Available from: http://www.ncbi.nlm.nih.gov/pubmed/16168781.

14. Bruni L, Diaz M, Castellsagué X, Ferrer E, Bosch FX, de Sanjosé S. Cervical Human Papillomavirus Prevalence in 5 Continents: Meta-Analysis of 1 Million Women with Normal Cytological Findings. J Infect Dis. 2010;202(12): 1789-99 [cited 2017 Nov 5]; Available from: http://www.ncbi.nlm.nih.gov/ pubmed/21067372.

15. Ogembo RK, Gona PN, Seymour AJ, Park HS-M, Bain PA, Maranda L, et al. Prevalence of Human Papillomavirus Genotypes among African Women with Normal Cervical Cytology and Neoplasia: A Systematic Review and Meta-Analysis. PLoS One. 2015;10(4):e0122488 [cited 2017 Nov 5]; Available from: http://www.ncbi.nlm.nih.gov/pubmed/25875167.

16. Wagner M, Bennetts L, Patel H, Welner S, de Sanjose S, Weiss TW. Global availability of data on HPV genotype-distribution in cervical, vulvar and vaginal disease and genotype-specific prevalence and incidence of HPV infection in females. Infect Agent Cancer. 2015:10(1):13 Dec 28 [cited 2017 Nov 5] Available from: http://www.ncbi.nlm.nih.gov/pubmed/25987893.

17. Anorlu RI. Cervical cancer: the sub-Saharan African perspective. Reprod Health Matters. 2008;16(32):41-9 Jan 21 [cited 2017 Nov 5] Available from: http://www.ncbi.nlm.nih.gov/pubmed/19027621.

18. Bouassa RSM, Prazuck T, Lethu T, Meye JF, Bélec L. Cervical cancer in subSaharan Africa: an emerging and preventable disease associated with oncogenic human papillomavirus. Med Sante Trop. 27(1):16-22 doi.org [Internet] 2017 Feb 1 [cited 2017 Nov 5] Available from: http://www.ncbi. nlm.nih.gov/pubmed/28406406. 
19. Sylla BS, Wild CP. A million africans a year dying from cancer by 2030: what can cancer research and control offer to the continent? Int J cancer. 2012; 130(2):245-50 [cited 2017 Nov 5]; Available from: http://www.ncbi.nlm.nih. gov/pubmed/21796634.

20. Institute for Health Metrics and Evaluation, Human Development Network, The World Bank. The Global burden of disease: Generating evidence, guiding policy Sub-Saharan Africa regional edition [Internet]. Seattle; 2013. [cited 2017 Nov 5]. Available from: http://www.healthdata.org/sites/default/ files/files/data_for_download/2013/WorldBank_SubSaharanAfrica/IHME_ GBD_WorldBank_SubSaharanAfrica_FullReport.pdf.

21. Akarolo-Anthony SN, Ogundiran TO, Adebamowo CA. Emerging breast cancer epidemic: evidence from Africa. Breast Cancer Res. 2010;12(S4):S8 [cited 2017 Nov 5]; Available from: http://breast-cancer-research. biomedcentral.com/articles/10.1186/bcr2737.

22. Jamison DT, Feachem RG, Makgoba MW, Bos ER, Baingana FK, Hofman KJ, et al. Disease and Mortality in Sub-Saharan Africa [Internet]. Disease and Mortality in Sub-Saharan Africa: The International Bank for Reconstruction and Development / The World Bank; 2006. [cited 2017 Nov 5]. Available from: http://www.ncbi.n/m.nih.gov/pubmed/21290641.

23. The World Bank. Population between the ages 0 to 14 as a percentage of the total population: The World Bank. [cited 2017 Nov 5]. Available from: https://data.worldbank.org/indicator/SP.POP.0014.TO.ZS.

24. Williamson A-L. The Interaction between Human Immunodeficiency Virus and Human Papillomaviruses in Heterosexuals in Africa. J Clin Med. 2015; 4(4):579-92 [cited 2017 Nov 5]; Available from: http://www.ncbi.nlm.nih.gov/ pubmed/26239348.

25. Narasimhan M, Pedersen H, Ogilvie G, Vermund SH. The case for integrated human papillomavirus vaccine and HIV prevention with broader sexual and reproductive health and rights services for adolescent girls and young women. Trans R Soc Trop Med Hyg. 2017;111(4):141-3 [cited 2017 Nov 5]; Available from: http://www.ncbi.nlm.nih.gov/pubmed/28673020.

26. De Vuyst H, Alemany L, Lacey C, Chibwesha CJ, Sahasrabuddhe V, Banura C, et al. The Burden of Human Papillomavirus Infections and Related Diseases in Sub-Saharan Africa. Vaccine. 2013;31:F32-46 [cited 2017 Nov 5]; Available from: http://www.ncbi.n/m.nih.gov/pubmed/24331746.

27. Ramjee G, Daniels B. Women and HIV in Sub-Saharan Africa. AIDS Res Ther. 2013;10(1):30 [cited 2017 Nov 5]; Available from: http://www.ncbi.nlm.nih. gov/pubmed/24330537.

28. Bhatla N, Dar L, Rajkumar Patro A, Kumar P, Pati SK, Kriplani A, et al. Human papillomavirus-type distribution in women with and without cervical neoplasia in north India. Int J Gynecol Pathol. 2008;27(3):426-30 [cited 2017 Nov 5] Available from: http://www.ncbi.nlm.nih.gov/pubmed/18580322.

29. UNAIDS. UNAIDS fact sheet - Latest statistics on the status of the AIDS epidemic. 2017 [cited 2017 Nov 5]. Available from: http://www.unaids.org/ sites/default/files/media_asset/UNAIDS_FactSheet_en.pdf.

30. Cutts FT, Franceschi S, Goldie S, Castellsague X, de Sanjose S, Garnett G, et al. Human papillomavirus and HPV vaccines: a review. Bull World Health Organ. 2007;85(9):719-26 [cited 2017 Nov 5]; Available from: http://www. ncbi.nlm.nih.gov/pubmed/18026629.

31. Macartney KK, Chiu C, Georgousakis M, Brotherton JML. Safety of Human Papillomavirus Vaccines: A Review. Drug Saf. 2013;36(6):393-412 [cited 2017 Nov 5]; Available from: http://www.ncbi.nlm.nih.gov/ pubmed/23637071.

32. Joura EA, Pils S. Vaccines against human papillomavirus infections: protection against cancer, genital warts or both? Clin Microbiol Infect. 2016; 22:S125-7 [cited 2017 Nov 5]; Available from: http://www.ncbi.nlm.nih.gov/ pubmed/28034371.

33. World Health Organization. Human papillomavirus vaccines. WHO position paper. 2009 [cited 2017 Nov 5]. Available from: http://www.ncbi.nlm.nih. gov/pubmed/19360985.

34. Marrero SL, Bloom DE, Adashi EY. Noncommunicable diseases: a global health crisis in a new world order. JAMA. 2012;307(19):2037-8 [cited 2017 Nov 5]; Available from: http://www.ncbi.nlm.nih.gov/pubmed/ 22665101.

35. World Health Organization. Global action plan for the prevention and control of noncommunicable diseases 2013-2020. 2013 [cited 2017 Nov 5]. Available from: www.who.int/about/licensing/copyright_form/en/index.html.

36. Knaul FM, Frenk J, Shulman L. Global Task Force on Expanded Access to Cancer Care and Control in Developing Countries (GTF.CCC) Harvard Global Equity Initiative Closing the Cancer Divide: A Report of the Global Task Force on Expanded Access to Cancer Care and Control. Boston; 2011. [cited
2017 Nov 5]. Available from: http://www.hst.org.za/publications/NonHST Publications/ccd_report_111027.pdf

37. Youngblood R. Global alliance for vaccines and immunization injects new life into human papillomaviru vaccine rollout. Lancet. 2013;381(9879):1688 [cited 2017 Nov 5]; Available from: http://www.ncbi.nlm.nih.gov/pubmed/23683613.

38. World Health Organization. Comprehensive Cervical Cancer Control A guide to essential practice. Geneve; 2014. [cited 2017 Nov 5]. Available from: http://apps.who.int/iris/bitstream/10665/144785/1/9789241548953_eng.pdf.

39. United Nations. Sustainable Development Goals. 2015 [cited 2017 Nov 5]. Available from: https://sustainabledevelopment.un.org/sdgs.

40. Ogembo JG, Manga S, Nulah K, Foglabenchi LH, Perlman S, Wamai RG, et al. Achieving high uptake of human papillomavirus vaccine in Cameroon: Lessons learned in overcoming challenges. Vaccine. 2014;32(35):4399-403 [cited 2017 Nov 5]; Available from: http://www.ncbi.nlm.nih.gov/pubmed/24968154.

41. Perlman S, Wamai RG, Bain PA, Welty T, Welty E, Ogembo JG. Knowledge and awareness of HPV vaccine and acceptability to vaccinate in subSaharan Africa: a systematic review. PLoS One. 2014;9(3):e90912 [cited 2017 Nov 5]. Available from: http://www.ncbi.nlm.nih.gov/pubmed/24618636.

42. Gakidou E, Nordhagen S, Obermeyer Z. Coverage of Cervical Cancer Screening in 57 Countries: Low Average Levels and Large Inequalities. PLoS Med. 2008;5(6):e132 [cited 2017 Nov 5]; Available from: http://www.ncbi. nlm.nih.gov/pubmed/18563963.

43. Binagwaho A, Wagner C, Gatera M, Karema C, Nutt C, Ngaboa F. Achieving high coverage in Rwanda's national human papillomavirus vaccination programme. Bull World Health Organ. 2012;90(8):623-8 [cited 2017 Nov 5] Available from: http://www.who.int/bulletin/volumes/90/8/11-097253.pdf.

44. Lynge E, Rebolj M. Primary HPV screening for cervical cancer prevention: results from European trials. Nat Rev Clin Oncol. 2009;6(12):699-706 10 [cited 2017 Nov 5]; Available from: http://www.nature.com/doifinder/10. 1038/nrclinonc.2009.167.

45. Saslow D, Runowicz CD, Solomon D, Moscicki A-B, Smith RA, Eyre HJ, et al. American Cancer Society guideline for the early detection of cervical neoplasia and cancer. CA Cancer J Clin. 52(6):342-62 [cited 2017 Nov 5]; Available from: http://www.ncbi.nlm.nih.gov/pubmed/ 12469763.

46. Adefuye PO, Broutet NJ, de Sanjosé S, Denny LA. Trials and Projects on Cervical Cancer and Human Papillomavirus Prevention in Sub-Saharan Africa. Vaccine. 2013;31:F53-9 [cited 2017 Nov 5]; Available from: http:// www.ncbi.nlm.nih.gov/pubmed/24331748.

47. Abdullahi LH, Kagina BM, Cassidy T, Adebayo EF, Wiysonge CS, Hussey GD. Knowledge, attitudes and practices on adolescent vaccination among parents, teachers and adolescents in Africa: a systematic review protocol. Syst Rev. 2014;3:100 [cited 2017 Nov 5]; Available from: http://www.ncbi. nlm.nih.gov/pubmed/25200458.

48. Viviano M, DeBeaudrap P, Tebeu P-M, Fouogue JT, Vassilakos P, Petignat P. A review of screening strategies for cervical cancer in human immunodeficiency virus-positive women in sub-Saharan Africa. Int J Womens Health. 2017;9:69-79 [cited 2017 Nov 5]; Available from: http:// www.ncbi.nlm.nih.gov/pubmed/28203108.

49. Finocchario-Kessler S, Wexler C, Maloba M, Mabachi N, Ndikum-Moffor F, Bukusi E. Cervical cancer prevention and treatment research in Africa: a systematic review from a public health perspective. BMC Womens Health. 2016;16(1):29 [cited 2017 Nov 5]; Available from: http://www.ncbi.nlm.nih. gov/pubmed/27259656.

50. Fokom-Domgue J, Combescure C, Fokom-Defo V, Tebeu PM, Vassilakos P, Kengne AP, et al. Performance of alternative strategies for primary cervical cancer screening in sub-Saharan Africa: systematic review and meta-analysis of diagnostic test accuracy studies. BMJ. 2015;351 [cited 2017 Nov 5]; Available from: http://www.bmj.com/content/351/bmj.h3084.

51. Ministry of Public Health and Sanitation, Ministry of Medical Services. National Cervical Cancer Prevention Program Strategic Plan 2012-2015. 2012 [cited 2017 Mar 19]. Available from: http://www.iccp-portal.org/sites/default/files/ plans/National Cervical Cancer Prevention Plan FINALFeb 2012.pdf.

52. Phillips-Howard PA, Laserson KF, Amek N, Beynon CM, Angell SY, Khagayi S, et al. Deaths ascribed to non-communicable diseases among rural Kenyan adults are proportionately increasing: evidence from a health and demographic surveillance system, 2003-2010. PLoS One. 2014;9(11):e114010 [cited 2017 Nov 5]; Available from: http://www.ncbi.nlm.nih.gov/pubmed/25426945.

53. Kenya National Bureau of Statistics, Ministry of Health, National AIDS Control Council, Kenya Medical Research Institute, National Council for Population and Development, The DHS Program ICF International. Kenya Demographic 
and Health Survey 2014. 2015 [cited 2016 Jul 4]. Available from: https:// dhsprogram.com/pubs/pdf/FR308/FR308.pdf.

54. Orang'o EO, Wachira J, Asirwa FC, Busakhala N, Naanyu V, Kisuya J, et al. Factors Associated with Uptake of Visual Inspection with Acetic Acid (VIA) for Cervical Cancer Screening in Western Kenya. PLoS One. 2016;11(6): e0157217 Natarajaseenivasan K, editor. [cited 2017 Feb 16] Available from: http://www.ncbi.nlm.nih.gov/pubmed/27310005.

55. Vermandere $\mathrm{H}$, Naanyu $\mathrm{V}$, Degomme $\mathrm{O}$, Michielsen $\mathrm{K}$. Implementation of an HPV vaccination program in Eldoret, Kenya: results from a qualitative assessment by key stakeholders. BMC Public Health. 2015;15(1):875 [cited 2017 Nov 6]; Available from: http://www.ncbi.nlm.nih.gov/pubmed/26358701.

56. Vermandere $H$, Naanyu V, Mabeya $H$, Vanden Broeck D, Michielsen $K$, Degomme O. Determinants of Acceptance and Subsequent Uptake of the HPV Vaccine in a Cohort in Eldoret, Kenya. PLoS One. 2014;9(10):e109353 Consolaro MEL, editor [cited 2017 Nov 6];: Available from: http://www.ncbi. nlm.nih.gov/pubmed/25299646.

57. Khozaim K, Orang'o E, Christoffersen-Deb A, Itsura P, Oguda J, Muliro H, et al. Successes and challenges of establishing a cervical cancer screening and treatment program in western Kenya. Int J Gynecol Obstet. 2014;124(1):12-8 [cited 2017 Nov 6]. Available from: http://www.ncbi.nlm.nih.gov/pubmed/ 24140218.

58. Rosser Jl, Hamisi S, Njoroge B, Huchko MJ. Barriers to Cervical Cancer Screening in Rural Kenya: Perspectives from a Provider Survey. J Community Health. 2015;40(4):756-61 [cited 2017 Feb 16]; Available from: http://www. ncbi.nlm.nih.gov/pubmed/25677728.

59. Morema EN, Atieli HE, Onyango RO, Omondi JH, Ouma C. Determinants of cervical screening services uptake among 18-49 year old women seeking services at the Jaramogi Oginga Odinga Teaching and Referral Hospital, Kisumu, Kenya. BMC Health Serv Res. 2014;14:335 [cited 2017 Feb 16]; Available from: http://www.ncbi.nlm.nih.gov/pubmed/25100298.

60. Rositch AF, Gatuguta A, Choi RY, Guthrie BL, Mackelprang RD, Bosire R, et al. Knowledge and Acceptability of Pap Smears, Self-Sampling and HPV Vaccination among Adult Women in Kenya. PLoS One. 2012;7(7):e40766 Medeiros R, editor. [cited 2017 Nov 6]. Available from: http://www.ncbi.nlm. nih.gov/pubmed/22808257.

61. Wamburu K, Busakhala N, Owuor K, Nyagero J. Association between stage at diagnosis and knowledge on cervical cancer among patients in a Kenyan tertiary hospital: a cross-sectional study. Pan Afr Med J. 2016;25(Suppl 2):15 [cited 2017 Nov 6]; Available from: http://www.ncbi.nlm.nih.gov/pubmed/28439339.

62. Masika MM, Ogembo JG, Chabeda SV, Wamai RG, Mugo N. Knowledge on HPV Vaccine and Cervical Cancer Facilitates Vaccine Acceptability among School Teachers in Kitui County, Kenya. PLoS One. 2015;10(8):e0135563 Hozbor DF, editor [cited 2017 Nov 6]; Available from: http://www.ncbi.nlm. nih.gov/pubmed/26266949.

63. Chidyaonga-Maseko F, Chirwa ML, Muula AS. Underutilization of cervical cancer prevention services in low and middle income countries: a review of contributing factors. Pan Afr Med J. 2015:21:231 [cited 2017 Nov 6]; Available from: http://www.ncbi.nlm.nih.gov/pubmed/26523173.

64. Gallagher KE, Howard N, Kabakama S, Mounier-Jack S, Griffiths UK, Feletto $\mathrm{M}$, et al. Lessons learnt from human papillomavirus (HPV) vaccination in 45 low- and middle-income countries. PLoS One. 2017;12(6):e0177773 Roy JK, editor. [cited 2017 Nov 6]; Available from: http://www.ncbi.nlm.nih.gov/ pubmed/28575074.

65. Wigle J, Coast E, Watson-Jones D. Human papillomavirus (HPV) vaccine implementation in low and middle-income countries (LMICs): Health system experiences and prospects. Vaccine. 2013;31(37):3811-7 [cited 2017 Nov 6]; Available from: http://www.ncbi.nlm.nih.gov/pubmed/23777956.

66. Abdullahi LH, Kagina BM, Cassidy T, Adebayo EF, Wiysonge CS, Hussey GD. Knowledge, attitudes and practices on adolescent vaccination among adolescents, parents and teachers in Africa: A systematic review. Vaccine. 2016;34(34):3950-60 [cited 2017 Nov 6]; Available from: http://www.ncbi. nlm.nih.gov/pubmed/27289251.

67. Ministry of Health K. Kenya STEPwise Survey for Non Communicable Diseases Risk Factors 2015 Report; 2015. p. 8-210. Available from: http:// aphrc.org/wp-content/uploads/2016/04/Steps-Report-NCD-2015.pdf.

68. Ndejjo R, Mukama T, Musabyimana A, Musoke D, Bonell C, Yeates K, et al. Uptake of Cervical Cancer Screening and Associated Factors among Women in Rural Uganda: A Cross Sectional Study. PLoS One. 2016;11(2): e0149696 Tornesello ML, editor. [cited 2017 Feb 17]; Available from: http:// dx.plos.org/10.1371/journal.pone.0149696.
69. Perng P, Perng W, Ngoma T, Kahesa C, Mwaiselage J, Merajver SD, et al. Promoters of and barriers to cervical cancer screening in a rural setting in Tanzania. Int J Gynaecol Obstet. 2013;123(3):221-5 [cited 2017 Nov 6]; Available from: http://www.ncbi.nlm.nih.gov/pubmed/24095307.

70. Sicsic J, Franc C. Obstacles to the uptake of breast, cervical, and colorectal cancer screenings: what remains to be achieved by French national programmes? BMC Health Serv Res. 2014;14(1):465 [cited 2017 Nov 6]; Available from: http://www.ncbi.n/m.nih.gov/pubmed/25282370.

71. Guo F, HIrth JM, Berenson AB. Effects of cardiovascular disease on compliance with cervical and breast cancer screening recommendations among adult women. J Women's Heal. 2015;24(8):641-7 Available from: abberens@utmb.edu.

72. Constantinou P, Dray-Spira R, Menvielle G. Cervical and breast cancer screening participation for women with chronic conditions in France: results from a national health survey. BMC Cancer. 2016;16(1):255 [cited 2017 Nov 6]; Available from: http://www.ncbi.nlm.nih.gov/pubmed/27029643.
Ready to submit your research? Choose BMC and benefit from:

- fast, convenient online submission

- thorough peer review by experienced researchers in your field

- rapid publication on acceptance

- support for research data, including large and complex data types

- gold Open Access which fosters wider collaboration and increased citations

- maximum visibility for your research: over $100 \mathrm{M}$ website views per year

At BMC, research is always in progress.

Learn more biomedcentral.com/submissions 